\title{
SACRAMENTOS E IDENTIDAD EN LA ÚLTIMA CANOA. TRAVESÍA DE UN KAWESKAR AL BORDE DEL MAPA ${ }^{1}$
}

\author{
Lorena López Torres \\ lorena.lopez@fu-berlin.de \\ Freie Universität Berlin \\ RESUMEN / ABSTRACT
}

El presente artículo ahonda en el conflicto identitario que el kaweskar experimenta en su interacción con los religiosos y militares que se emplazan en las márgenes de Puerto Edén, zona periférica en la que son confinados los escasos descendientes. Dentro de sus fronteras los niños kaweskar inician un proceso educativo que difiere con los patrones de aprendizaje de su etnia, adquiriendo costumbres y conocimientos coincidentes con los preceptos de la religión católica. Wegmann cuestiona el perfil identitario que la nación chilena ha instaurado a nivel macro y la supuesta integración de los indígenas como ciudadanos chilenos.

Palabras Clave: identidad, kaweskar, otredad, colegios-internados, sacramentos.

This article explores the identity conflict that the Kaweskar experience in interacting with religious and military groups located on the shores of Puerto Eden, a peripheral zone where few descendants are confined. Within these borders Kaweskar children begin an educational process that differs from the learning patterns of their ethnicity, thus assimilating customs and knowledge based on the precepts of the Catholic religion. Wegmann questions the identity profile that the Chilean nation has set at a macro level and the alleged integration of indigenous people as Chilean citizens.

KEY WORDS: identity, Kaweskar, otherness, boarding school, sacraments.

${ }^{1}$ Una primera versión fue leída en las VIII Jornadas Andinas de Literatura Latinoamericana JALLA, Universidad de Chile, 11-15 de agosto de 2008 y forma parte de mi tesis titulada CUENTAS POR ALMAS: Las misiones y el rapto indígena en la literatura magallánica del siglo $X X$, con la cual obtuve el grado de Magíster en Literatura Hispanoamericana Contemporánea de la Universidad Austral de Chile en enero de 2010. Igualmente se inserta en el proyecto FFI2008-05029 (Ministerio de Ciencia e Innovación, Secretaría de Estado de Investigación) titulado Cultura y fronteras: la literatura y sus aportaciones a la configuración imaginaria de la Araucanía y la Patagonia, dirigido por el Dr. Teodosio Fernández Rodríguez de la Universidad Autónoma de Madrid. 


\section{INTRODUCCIÓN}

Osvaldo Wegmann Hansen (1918, San Julián, Arg.-1987, Punta Arenas), uno de los narradores magallánicos más importantes de la región, comienza a escribir a los 17 años en la revista Juventud de su colegio -el Liceo Salesiano San José. Su primer cuento, "El Caleuche", es incluido en la obra de Nicomedes Guzmán Nuevos cuentistas chilenos (1941), entre una veintena de escritores del norte y del sur. "El cementerio de los milodones" y "La horma de su zapato" han sido incluidos en la Antología del cuento chileno (1985) de Enrique Lafourcade. En su amplia producción destacan obras como Tierra de alacalufes (1953), El sueño del ballenero (1968), La tierra de las discordias (1955) y la novela que hoy nos convoca La última canoa (1976), lectura que remece las letras regionales desde mediados del siglo XX.

La novela de Wegmann es una suerte de documentación del proceso de aclimatación del kaweskar al sistema de control impuesto por la sociedad chilena con la asistencia de sus bases militares emplazadas en la zona austral. Los kaweskar ${ }^{2}$-pueblo canoero y nómada- habitaban los canales y fiordos del estrecho de Magallanes entre el Golfo de Penas y la Isla Grande de Tierra del Fuego. Compartían el suelo marítimo y terrestre con otros grupos étnicos cercanos, los yaganes, los haush -también canoeros-y los onas -habitantes de tierra firme con los que tenían un sistema de trueque cuando no de enfrentamiento bélico.

Petáyem, el protagonista, crece al amparo de la alicaída política proteccionista de las reducciones religiosas cuyas puertas se cierran ante la evidente merma de la población indígena ${ }^{3}$. Ante esta situación el gobierno acciona medidas de protección para los fueguinos que rondan las cercanías de las bases militares

${ }^{2}$ La etnia kaweskar -también conocidos como alacalufes-, desciende de los primeros pobladores que habitaron desde hace aproximadamente 6.000 años los canales patagónicos chilenos. El nombre kawéskar significa literalmente "ser racional de piel y hueso". Habitaban desde el paralelo 48 hasta el 53 de latitud sur, disponiendo incluso de un haruwen (territorio) en la isla de Tierra del Fuego. Son individuos morenos de afiliación mongoloide, ojos oblicuos, pómulos salientes, dentadura blanca y fuerte. De acuerdo con Alberto de Agostini medían 1,66 metros aproximadamente (Vega Delgado 63).

${ }^{3}$ La misión de San Rafael, fundada en 1888, y la misión del Buen Pastor, fundada en 1898, ambas en Isla Dawson. Para 1911, ambas misiones se han cerrado. La Misión Nuestra Señora de la Candelaria de Río Grande, fundada en 1893, se cierra a principios de 1920 pues ya no hay masa indígena (Odone y Mege 41) Entre las causas de su extinción se cuentan las enfermedades y el alcohol, además de los constantes abusos y matanzas por parte de los blancos. 
instaladas en la periferia insular de la región. En una primera instancia estas medidas solo se instauran para proveer a los indígenas de un abastecimiento básico, más bien precario, de alimentación y vestuario en sus esporádicos encuentros, dado el carácter nómade de la raza; posteriormente se hace imperativo albergar a algunas familias en las estaciones para procurarles una atención más efectiva y constante. Los alacalufes se han habituado a ser sostenidos en sus necesidades básicas, siendo sus correrías por los canales cada vez menos frecuentes.

La participación del gobierno solo finiquita la mala maniobra de incorporación de los indígenas a la sociedad iniciada por los misioneros protestantes y salesianos. El intervencionismo del Estado responde a su interés de insertar al indígena en el sistema regular de educación, cuya finalidad es transformarlo en ciudadano y trabajador formal de la nación. Este proceso será asistido por la Congregación Salesiana que para ese entonces cuenta con colegios-internados en la ciudad de Punta Arenas. Para ello se renueva la política misional de los salesianos, acercándose a las masas indígenas que pululan cerca de las bases.

\section{I.- NACIMIENTO DE LA BASE-MISIÓN}

Da mihi animas caetera tolle (Dame almas, llévate lo demás).

Don Juan Bosco

Uno de los primeros espacios-enclave destinado a confinar a los alacalufes es la bahía de Puerto Edén ( $49^{\circ} 08^{\prime}$ S Sur, $74^{\circ} 27^{\prime}$ ' Oeste), ubicada “en la ribera oriental de la Isla Wellington, en un lugar adonde solo se puede llegar por vía marítima y a una distancia que se traduce en más de un día de navegación desde el centro más cercano" (Clairis 27). Es una zona estratégica, cuya particular composición periférica la hace idónea para concretar las intenciones del Estado ${ }^{4}$. Esta primera estación se establece en 1937 bajo la supervisión de

${ }^{4}$ El objetivo inicial del Estado en estas tierras era unir Santiago y Magallanes a través de un servicio de hidroaviones. La empresa fracasa, por lo que la base se transforma en una estación metereológica controlada por la Aviación (Martinic 2002). 
la Fuerza Aérea de Chile ${ }^{5}$ cuando la población de alacalufes suma alrededor de 120 habitantes $^{6}$. Paulatinamente la base se transforma en una pequeña villa $^{7}$ en la que conviven kaweskar, chilotes y militares, generándose mutuas influencias, sobre todo comerciales. El crecimiento de esta población señala la lenta incorporación de los territorios aislados a la geografía nacional y la desaparición de los aborígenes en estos últimos intentos reduccionistas.

La convivencia inicial es armónica: los indígenas reciben raciones diarias de alimento y éstos a su vez salen a recolectar mariscos, alimento que suelen compartir con los chilenos. Persistiendo en la ruta de los canales a bordo de sus canoas, siguen la huella de la ballena varada, ausentándose por largos periodos para alimentarse de la carne del gran cetáceo.

Petáyem vive los albores de la base; de niño es internado en un colegio salesiano de la capital provincial y en su adolescencia es trasladado a estudiar a Santiago en la Escuela de Aviación. Se hace adulto, trabaja, se casa y vive como cualquier chileno, renegando de su pasado y de sus orígenes ${ }^{8}$. En estos años Petáyem deja de ser el "otro" remiso, transformándose en un aprendiz de ciudadano.

${ }^{5}$ Durante los primeros 12 años de existencia la base es dirigida por el sargento Carlos Gaymer Gómez. Con ayuda de su familia, el militar se dedica a educar y capacitar a los kawésqar que llegan a vivir alrededor del puesto (www.kawesqar.uchile.cl).

${ }^{6}$ En 1883, José Fagnano confirma que existen 2.500 alacalufes (Ygobone 57). En la novela se afirma que la población es de aproximadamente 100 alacalufes (Wegmann 31).

7 Se instala además un Retén de Carabineros, una Posta de Primeros Auxilios, una Escuela Básica y un Registro Civil, todo lo necesario para asistir a la emergente población. En 1963, cuando los kaweskar contaban con algunos pocos descendientes, las autoridades les construyen unas casitas prefabricadas CORVI. Desde 1973 cuenta con un almacén de la Empresa de Comercio Agrícola (ECA) (Clairis).

${ }^{8}$ No existen antecedentes de que Wegmann se haya inspirado en la vida del kaweskar Lautaro Wellington para escribir su novela, pero las semejanzas entre ambos personajes son muchas. Joseph Emperaire habla de Wellington en Los nómades del mar (2002): "Un joven alacalufe de unos diez años, que parecía particularmente despierto, fue enviado hacia 1940 a Santiago, a una escuela de la Fuerza Aérea. (...) En 1947, después de 8 años de vida urbana, Lautaro Edén Wellington, según su nuevo nombre, ahijado del Presidente de la República, suboficial mecánico de aviación, desembarcaba en Edén, con un primer permiso de un mes. (...) Lautaro pasó otros dos años en Santiago y durante ese periodo se casó con una enfermera. En 1949, regresó sin su mujer a Puerto Edén, designado provisionalmente para ocupar las funciones de radio en la estación que debía dirigir más tarde" (Emperaire 126-127). Huelga decir que la idea original era civilizarlo para que después él hiciera lo propio con los suyos, pero el plan falló, con un desenlace semejante al de Petáyem. 
Larraín señala que el "otro", aquel que no es igual a mí, debe ser revertido en una suerte de sometimiento; es una construcción dual del sí mismo en oposición de la existencia del "otro", que se diferencian mutuamente debido a su carácter distintivo y específico. La existencia del otro opera en relación con un modo de vida, valores, costumbres e ideas diferentes. En el acelerado transcurso de la imposición de una identidad se exacerban las diferencias con los que están fuera, situación que genera interrogantes en el joven Petáyem. En estos casos el proceso de diferenciación se transforma en un proceso de abierta oposición y hostilidad al otro, (pues) constituye un peligro de todo proceso identitario (Larraín). Este sometimiento se sustenta en un complejo sistema -ejecutado por los agentes operadores del Estado y la Iglesia- que mezcla preceptos educacionales y cristianos negando la cultura del "otro", utilizándola a su antojo como herramienta evangelizadora, extirpada de su real dimensión y significado. El fin último es homogeneizar la cultura chilena a través de una ordenación identitaria que resuelva para los indígenas su inclusión en la sociedad "civilizada". Se reprimen entonces la diversidad y la heterogeneidad, por lo tanto, la identidad debe ser jerárquicamente establecida como una sola. Marc Guillaume afirma que en el intento de homogenizar y hacer valer la hegemonía por sobre la diversidad y pluralidad de identidades se anula la alteridad radical que el indígena representa: ese otro es el ausente de la historia que "incluye al extraño, a aquel que no soy yo" (44). Es una inclusión que "se funda en la eliminación de las diferencias, en la eliminación de la alteridad radical" (47). De esta manera se anula toda posibilidad de diálogo -y de expresión- con el conocimiento subalterno, como Mignolo lo llama; por lo tanto, el sometimiento de los fueguinos alcanzaría los horizontes del lenguaje: la abolición de los dialectos borra la memoria, los mitos y tradiciones de esta raza; en consecuencia, el bilenguajear mignoliano (350) no tendría cabida. Anderson señala que la muerte de las lenguas aborígenes significó la muerte de las etnias ya que la imposición del español para la unificación de América Latina solo resolvió que paganos y salvajes se convirtieran sin comprender lo esencial de los dogmas cristianos. Los fueguinos se ven forzados a interpretar sus propias lenguas como manifestaciones sonoras de lo diabólico, lo que deja en evidencia que la evangelización no promueve una auténtica conversión desde el interior con conocimiento por parte de los europeos de las diferentes culturas y 
lenguas de la Patagonia ${ }^{9}$. Más bien opera un mecanismo de naturalización, por medio del cual los que no son miembros de la nación acceden a ella en calidad de "invitados" a hablar la lengua oficial (Anderson). Los alacalufes son "invitados/forzados" a integrar la comunidad imaginada chilena, pero en desmedro de sus saberes, comunicándose en otro idioma y obedeciendo leyes opuestas a su cosmovisión. Las políticas proteccionistas del Estado y de los salesianos concuerdan tomando una misma dirección: la educación y la religión católica son el medio de salvación e inclusión para los indígenas.

Según los postulados de la teoría postmoderna de la comunicación, el concepto de identidad consistente en un "proceso de contacto entre dos agentes en un acto comunicativo: entre el sujeto y el objeto (...) es un proceso dialógico de la diferenciación del "yo" y del "otro" (Kulawik 24-25), en que se respetan y se entienden las diferencias, incluso las que son internas. Pero una relación entendida así - diádicamente-no siempre es tal, la tendencia es a invisibilizar al inferior, por eso dentro de la comunidad-nación se tiende a anular la alteridad radical, como postula Guillaume.

Dentro de la misión educacional, Petáyem se adhiere a las normas que establece la autoridad para su incorporación: el sacramento bautismal y el nuevo nombre; el cambio de hábitat y la educación formal. El último paso llega en la etapa de madurez del protagonista debatiéndose trágicamente entre dos opuestos: ¿chileno o kaweskar? El porqué de este cuestionamiento habla del menoscabo de su vida como actor social participe, la insatisfacción y la discriminación percibida sin dar a conocer sus orígenes.

Los dos agentes reguladores -gobierno y salesianos-deciden el presente y el futuro del indígena; aunque en una primera instancia los militares dirijan el destino del alacalufe, los sacerdotes serán los encargados de guiar sus pasos camino a la civilización.

\section{II.- SACRAMENTOS Y DOCTRINA CATÓLICA}

Al cerrarse las puertas de las misiones salesianas, los sacerdotes extienden su labor a los remanentes que se albergan alrededor de las bases militares. Las

${ }^{9}$ El ejemplo de Thomas Bridges es excepcional; aprendió el yámana con una pareja nativa para luego traducir algunos evangelios y poder predicar a los indígenas en su propia lengua. En cuanto a los kaweskar, no se aplicó una metodología semejante. 
visitas de los religiosos son esporádicas y su objetivo misional -el que antes ostentaba sacrificio y protección para los indígenas en sus reductos- hoy solo procura mantenerse vigente mediante un único requerimiento eclesiástico: el bautismo. A través de este sacramento creen alcanzar la conversión indígena, pero los conceptos son mal entendidos y confundidos durante dicho proceso. $\mathrm{M}^{\mathrm{a}}$ Andrea Nicoletti explica estos tópicos: "Civilizar significa vivir en poblado con casa y familia, cultivar la tierra, criar ganado, respetar la propiedad ajena y administrar los bienes. Bajo este concepto existían determinados aspectos por civilizar en los indígenas, manifestando así un grado de cristianización que debían alcanzar con su prédica" (Nicoletti 251). En este orden, la conversión administrada en las misiones tenía como fin último un adoctrinamiento que provocara un cambio sustancial en los hábitos de los fueguinos ${ }^{10}$.

El sacerdote Don Juan Bosco, fundador de la Congregación Salesiana en Turín (Italia) plasma en sus memorias ${ }^{11}$ su estrategia misional derivada de una serie de sueños proféticos -o sueños geográficos como los llama Juan E. Belsa porque describen los territorios, los ríos que los surcan, montañas y bosques (Cit. en Blengino)- que habría tenido el santo, y que motivan la llegada de los salesianos a la Patagonia. Sus discípulos comparten el fetiche positivista del número: cantidad de almas es igual a cantidad de conversos. Entonces, el concepto conversión es desvirtuado y por ende el sacramento bautismal se masifica. Para Don Bosco los indios son salvajes y fieles que desconocen la verdad por ignorancia y no por falta de inteligencia. En este sentido, solo el misionero con su conducta de paz y con la religión como arma puede civilizarlos. Por lo tanto, el indio infiel es llamado "no bautizado", cuando lo correcto sería llamarlo "no convertido" (Nicoletti 249).

En el abra de Puerto Edén el bautismo es reservado casi exclusivamente para los más pequeños; para los propósitos misionales no es de gran utilidad bautizar a los mayores, pues estos carecen de la inocencia y disposición de

${ }^{10}$ Civilización, cristianización y conversión son conceptos que adquieren relevancia con la aparición de la antropología ilustrada y positivista del siglo XIX. Civilización y cristianización se funden en dos tipos de sistemas de evangelización: las misiones volantes y reduccionales (Nicoletti 251).

${ }^{11}$ Memorias biográficas de San Juan Bosco (1935), compiladas y publicadas en 19 volúmenes por Giovanni Battista Lemoyne, Ángelo Amadei y Eugenio Ceria. Contienen 200 sueños, 6 de los cuales corresponden a la Patagonia: una fantasía con los ojos abiertos de 1856; una parábola de la región de 1872; vocación misional de 1881; sueño de América Meridional de 1883; futuro de las misiones de 1885 y futuro de la Congregación de 1886 (Blengino 126). 
los niños. Llevar a cabo la tarea evangelizadora entre ellos significa menor esfuerzo para los sacerdotes en vista de la disciplina y la inteligencia que demuestran. Sin embargo, la evangelización no se hace desde el interior, es decir, desde la lengua kaweskar ${ }^{12}$; era lógico que con el bautismo los indígenas adoptaran el español como su verdadera lengua abandonando la persistencia del dialecto del Diablo. En la novela, el padre Torres lo expresa claramente:

-¿Cómo hace usted para aprender esa jerigonza? (al sargento de la base). Yo nunca he podido meterme en la cabeza una palabra de tan endemoniado dialecto.

-Sin embargo, el padre Beauvoir confeccionó un pequeño diccionario, con palabras de los alacalufes.

-A él le encantaba todo esto. A mi no. Soy partidario de enseñarles castellano y de que adopten nombres cristianos, aunque a usted no le guste mucho (Wegmann 39).

Sorprendente reacción, considerando que-como pocos-Beauvoir ${ }^{13}$ consideraba que la comprensión de la lengua era una herramienta indispensable para acercarse al indígena. La postura del padre Torres deja en claro desde un principio cuál es la orientación de su misión itinerante: imponer la cultura dominante y -si leemos más a fondo-obtener para sí mismo la redención a través de su entrega de fe hacia el salvaje.

Para la Iglesia la conversión significa apartarse del pecado y según su lectura el pecado en los alacalufes implica abandonar sus costumbres ajenas a la fe católica como son la poligamia, la embriaguez y los ritos paganos.

En la sociedad kaweskar el hombre puede tener más de una mujer, lo que no problematiza la constitución del núcleo familiar, pero dentro de la lógica cristiana, este tipo de costumbres representan un peligro para su eventual civilización, es -según la doctrina del padre Torres-la persistencia del demonio. La administración oportuna del bautismo contrarresta el poder de Satanás salvando al indígena de las tinieblas y la ignorancia. Su naturaleza bárbara y primitiva es consecuencia del yugo satánico que los abstrae de toda noción

12 Dura tarea para los misioneros italianos: debían aprender el español y el kaweskar al mismo tiempo. Esta dificultad hace imposible pensar que la prédica llegara a realizarse en lengua nativa.

${ }_{13}$ Beauvoir, al igual que Don Bosco, pensaba que los indígenas eran difíciles de someter por su naturaleza libre e indómita. El plan evangelizador es noble solo por la búsqueda de salvación por la fe y la civilización (Nicoletti). 
cultural y religiosa; por lo tanto, el deber del sacerdote es educarlos en la fe. Esta labor debe ser sistemática, puesto que tanto militares como fueguinos se olvidan de la doctrina y los convencionalismos impuestos:

Yo estuve aquí el año pasado y les dí el bautismo. Pero no los identifico por sus nombres paganos, sino que por los nombres cristianos que les hemos dado. Así, por ejemplo: Gregorio Mansilla...

-Ese es Noshtué.

-Jóse Flojo.

-Es Takerá.

No los llamen con esos nombres. Es horroroso. Todos tienen que llevar nombres cristianos.

-No le discuto eso -alegó el sargento Sandoval-; pero me parece que es bonito conservarles sus nombres autóctonos. A mí me gustan. Por lo demás no creo que eso de llamarse Takerá o José sea condición u obstáculo para ir o no al cielo cuando mueran (Wegmann 24).

Petáyem, como otros kawaskar de su edad, no está bautizado; vive presa del demonio, por lo tanto, no es hijo de Dios y eso aterra al sacerdote. Pero la administración del bautismo no se reconoce como un acto de buena fe entre ambas partes; para conseguir su objetivo, los religiosos aplican estrategias misionales para atraer la atención de los mayores y ganarse la confianza de los pequeños. Un ejemplo es el sistema de agasajo en que los salesianos regalan algún objeto de poco valor a los indígenas adultos para quedarse con sus hijos. Esta era la estrategia inicial implementada por Don Bosco en su plan misional: "comprar o pedir mediante diversos regalos a estos niños para bautizarlos y educarlos luego cristianamente" (Nicoletti 326) ${ }^{14}$.

Como consecuencia del sacramento bautismal se avecina el cambio de nombre para el otrora indígena rebelde. Tiene que ser un nombre cristiano acorde con su nueva vida de alacalufe converso. Para Petáyem el cambio nominal es significativo; es consciente de que no volverá a ser llamado por su nombre nativo: "El primero en recibir este sacramento fue Petáyem, a quién bautizaron Pedro Lientur Messier. Su padrino fue el cabo Aguilar,

${ }^{14}$ El agasajo se corresponde con la noción de rapto que aparece en otro artículo mío titulado "Isómeros de hombre a bordo del Beagle. Inclusión, rapto y alteridad en Jemmy Buttom de Benjamín Subercaseaux", que forma parte del volumen Darwin y el darwinismo: 150 años después (2011), publicado por UNSAMedita de la Universidad Nacional de San Martín. 
quien estuvo a su lado y mantuvo una mano sobre su hombro" (Wegmann 45). Este primer paso chilenizador indica el quiebre inicial en el interior del personaje, y del mismo con su cultura. Religiosos y militares auxilian en este tránsito inicial al niño, de la misma forma en que ambos agentes se sostienen mutuamente en esta tarea.

Es interesante destacar que los nombres cristianos a los que recurre el sacerdote durante el bautismo muchas veces alcanzan tintes peyorativos -por ejemplo José Flojo- que no concuerdan con el sentimiento de inclusión con que pretenden revestir la ceremonia. El bautismo se funda en la certeza de que no existe posibilidad de diálogo con este otro, pues el conocimiento kaweskar es inferior y demoníaco; el conocimiento subalterno indígena es silenciado en pos de una homogeneidad del lenguaje (Mignolo) que indique el grado de avance de la cultura en el proceso de incorporación en el que son sometidos. En la primera parte de la novela, Petáyem es un personaje silencioso y silenciado por las acciones de los mayores y como consecuencia en el relato se muestra observante, obediente, pero también ansioso de conocer su futuro; mientras tanto, sacerdote y militares maquinan a su alrededor sin considerar sus inquietudes.

El nuevo nombre de Petáyem es aceptado por sus padres -bautizados anteriormente por el sacerdote; la unción es recibida sin objeción alguna, sin embargo, su familia continuará llamándolo por su antiguo nombre, el verdadero. Pasarán meses antes de que el niño comprenda hacia dónde se dirigen sus pasos; el nombre cristiano confirma el advenimiento de una nueva vida que se inicia en Punta Arenas. Fuera de los límites de su amada bahía, será llamado simplemente Lientur Messier: "Llevaría su nombre de bautizo, con tanta naturalidad, como si siempre se hubiera llamado así, y alguna vez habría de sorprenderse, porque volvieran a llamarle a la manera nativa" (Wegmann 173).

Ni siquiera la masividad del sacramento reviste reales connotaciones espirituales y ceremoniales en la vida de los indígenas; para los alacalufes esta es la ocasión perfecta de satisfacer ciertas necesidades a las que los mismos chilenos los han acostumbrado: "Los adultos recibieron el bautismo sin mayor emoción, $\mathrm{y}$, apenas terminada la ceremonia, comenzaron a reclamar obsequios. Pedían cigarrillos y café. (...) Estos pobres indios se dejan poner el agua bendita, con la misma indiferencia con que permiten que yo les coloque inyecciones: sin saber para qué" (Wegmann 45).

A través de este simple y común acto para cualquier cristiano, la existencia del indígena es alterada; el bautismo es un acto de fe y de creencia absoluta en un dios, pero los indígenas no logran entender al Dios cristiano ni la 
simbología que encierra la ceremonia bautismal. La conversión opera instando a los indígenas a abandonar sus ritos paganos y adoptar la fe unificadora, pero la respuesta de los kaweskar es guiada por el instinto y la necesidad. Martín Gusinde señala que "la forma religiosa de los halakwulup registra la típica creencia en un dios supremo (Cit. en Vega Delgado 70-71); mientras que Joseph Emperaire afirma que: "la existencia de un ser superior bueno no tiene prácticamente lugar en la vida religiosa de los alacalufes" (Emperaire 70-71). Opiniones paradójicas, lo cierto es que los alacalufes adultos no comprenden la profundidad del dogma católico; aun si se reconocen algunos paralelismos simbólicos en sus religiones, no resultan ser presa fácil para los catequistas. Los hijos, en cambio, transitan sin mayor dificultad entre sus aún poco arraigados preceptos nómades y una precoz enseñanza bajo parámetros occidentales, pues aún no han atravesado el umbral de los ceremoniales religiosos, por lo que desconocen su trascendencia. Esta es la razón por la cual la misión itinerante del padre Torres se concentra solo en ellos. En este punto los salesianos y el Estado parecen no poder sincronizarse. Mientras el salesiano intenta educar en la fe, las lecciones de Petáyem en la base militar -impartida por el sargento Sandoval y el cabo Aguilar- se aleja de toda noción cristiana: lo principal es que el niño aprenda a leer y escribir. De esta forma se comprende que el sacramento sea adoptado de manera más bien mecánica e impuesta; por ende, la educación brindada por los militares no es suficiente ni acorde con los propósitos evangelizadores:

El pequeño alacalufe aprendió ese día nuevas letras y formó palabras. Su maestro, consciente de que enseñaba a un indio, con buen sentido pedagógico, trataba de que no hubiese conceptos abstractos en sus lecciones y, en todo caso, los suprimía. Felizmente el silabario era ilustrado y el alumno aprendía cosas concretas: ojo, mamá, papá, rueda (Wegmann 87).

Pero aunque las propuestas entre un agente y otro no parecen coincidir, el sacerdote no puede prescindir de la asistencia militar; sin ellos el remanente alacalufe en la base se disgregaría y su misión se vería aún más complejizada.

El paso obligado es el traslado de los niños a la ciudad para proseguir su educación: Lientur Messier iniciará su etapa escolar en el colegio-internado ${ }^{15}$

${ }^{15}$ A diferencia de lo sucedido en las misiones volantes o reduccionales con las que tuvieron más éxito los misioneros anglicanos, en los colegios-internados de los salesianos los indígenas 
de los salesianos en Punta Arenas. La Congregación Salesiana en Punta Arenas desarrolla su proyecto educacional concentrándose en las capas jóvenes de la comunidad magallánica y ofreciendo refugio a los niños indígenas y pobres de la zona rural de la región. Estos primeros centros educacionales ${ }^{16}$ se fundan cuando sus reductos misionales están aún en funcionamiento y constituyen una nueva estrategia misional para movilizar a los indígenas jóvenes hacia el centro neurálgico de la región, de manera de alejarlos de las influencias negativas de terceros y de su misma gente. El responsable de este nuevo sistema misional es el discípulo de Juan Bosco, el sacerdote italiano José Fagnano, quien llega a la ciudad el 21 de julio de 1887.

El proyecto del padre Torres sigue los planteamientos de Fagnano al concentrar sus esfuerzos en la educación de los más pequeños. Para asegurar el éxito de su empresa, el italiano elabora un nuevo modelo de adoctrinamiento bajo la modalidad de colegios-internados, arrancando a los niños kaweskar de su hábitat natural. Persiguiendo el sueño de Don Bosco, Torres desea conseguir fondos del Estado para fundar un colegio y una iglesia en Puerto Edén; para ello, el sacerdote exhibe a la comunidad magallánica sus anhelos encarnados en Petáyem.

Existe una diferencia cualitativa en la enseñanza recibida por estos niños kaweskar y la de los recluidos en las misiones; estos últimos solo fueron instruidos en labores menores como agricultura, hilado, costura o carpintería de manera de que generaran el sustento diario de la misión y aprendieran a autoabastecerse por sí mismos al vivir fuera de las reservas (Canclini 1951).

Como pocos, Lientur tendrá acceso a una educación que en un principio se asemeja a la de cualquier niño chileno; esta medida genera desagrado en la población puntarenense, que no ve con buenos ojos que sus hijos compartan el aula con indios. La Iglesia Católica no escapa a las críticas sobre su responsabilidad en la situación que experimentan los pequeños indígenas; muchas veces acusa ignorancia e incita la conducta de los demás actores sociales en cuanto al estigma que pesa sobre estos "seres primitivos"

reciben una educación ampliada a materias como matemáticas, historia y ciencia, las cuales no formaban parte del plan inicial de instrucción habilitados en las misiones. Al respecto de las misiones sírvase revisar el artículo "Conversión y civilización en las misiones salesianos de la Patagonia", de Andrea Nicoletti, que aparece en Investigaciones y ensayos de la Academia Nacional de la Historia, No 48, Enero-Dic. Buenos Aires: pp. 321-353.

${ }^{16}$ Los colegios se fundan en Punta Arenas en 1887 (Kuzmanich 1990) y en Porvenir en 1898 (Zúñiga 1998). 
que han aprendido malamente "algunas manifestaciones de nuestra cultura" (Wegmann 100). Lientur nunca experimentó humillaciones ni malos tratos en su vida en la base; ahora por primera vez es testigo de opiniones estereotipadas sobre su raza por parte de algunos compañeros, sintiendo el apremio de la prematura madurez:

Petáyem que era el mayor y el que estaba más vinculado a la vida civilizada, sentía con dolor esta situación humillante. Comprendía que eran indiecitos, objeto de curiosidad de todos. Pero ¿por qué? ¿por el solo hecho de haber nacido en Puerto Edén? No encontraba otra justificación. Eran iguales a los demás niños del colegio. Además muchos de ellos se parecían a sus hermanitos que quedaron en la isla. Sus compañeros los llamaban despreciativamente chilotes... (Wegmann 186).

Pero la confrontación con nuevos hábitos, conocimientos y la adversidad de transitar en medio de una sociedad hostil y escandalizada por su "alteridad" se contrapone con el triste espectáculo de la vida en la base y los sentimientos que su imagen le genera. Las relaciones y su entorno han variado de acuerdo a los hábitos adoptados en la ciudad e internamente su espíritu se ha resentido por las diferencias que lo alejan de los suyos. Igualmente su familia lo desconoce y rechaza. Sin embargo, su decisión de obedecer el plan establecido por militares y salesianos responde también a un anhelo personal de asegurar un futuro más amable para su familia y hermanos de raza.

En este nuevo periodo de su educación moral y espiritual, Lientur adopta y adapta a su tambaleante taxonomía cultural nuevos elementos con los cuales se identifica. En su mente los conocimientos ancestrales son suplantados por saberes que memoriza en la escuela. En el colegio-internado parece sentirse cómodo entre los demás niños; paulatinamente dejarán de observarlo con la curiosidad de antaño pasando "inadvertido entre todos los chicuelos del curso" (Wegmann 10). Su rutina en el colegio no se aparta nunca de los deberes de cualquier niño educado en la fe católica, realizando actividades básicas como ir a la iglesia, al oratorio festivo o de paseo, siempre en compañía de un coadjutor -laico que asiste a los religiosos en las labores de enseñanza:

Ya no dormía en la antigua pieza. Ahora tenía una cama en el dormitorio grande, con todos los pupilos, que eran buenos chicos y que igual que él, procedían del campo o de localidades cercanas. 
Con ellos participaba en los juegos y, sobre todo en el fútbol, y con ellos también convivía especialmente los fines de semana, cuando no había clases y los demás alumnos no llegaban (Wegmann 10).

\section{III.- ¿CHILENO Ó KAWESKAR?}

Lientur sigue las órdenes del Presidente y se traslada a estudiar a la Escuela de Aviación en Santiago: "Era un mozo de más de dieciséis años, que había terminado la escuela primaria y comenzado la secundaria" (Wegmann 33). Es muy inteligente, pero también su aparente fragilidad debido a su calidad de indígena, hace que una serie de operaciones proteccionistas avalen la actitud paternalista de la autoridad. En la Escuela se encuentra con un grupo numeroso de novatos entre los cuales su presencia no genera mayor expectación. Nadie se acerca a observarlo con curiosidad, muy por el contrario, el trato militar es severo y por primera vez en mucho tiempo siente su soledad. El padre Torres ya no lo acompaña, las escenas de la bahía no lo inundan con la urgencia de antes, y sus juegos de niñez en el colegio-internado han dado paso a relaciones de convivencia maduras y serias.

Se siente parte de la comunidad-nación que le ha abierto -medianamentesus puertas (Anderson) y ya no lo señalan como el sujeto "diferente" por su aspecto, lengua o credo, puesto que ha perdido su alteridad radical que lo diferenciaba de los chilenos y lo hacían reconocerse a sí mismo como kaweskar (Guillaume). En la Escuela es uno más entre los trabajadores y circula con normalidad entre los ciudadanos de la gran capital; parece cumplir con las expectativas de la evangelización. Su positiva respuesta a las normas de la enseñanza católica lo catapulta a la esfera espiritual como hijo de Dios, aparentemente a la altura de los miembros de la sociedad cristiana. Lientur parece no advertir en plenitud esta transformación y en el intertanto trabaja: "Petáyem era un engranaje más de la inmensa maquinaria de la maestranza. Trabajaba. Trabajaba incesantemente sujeto a un horario estricto, que cumplía con entusiasmo, ávido de aprender y de surgir, de ascender en la carrera, de ser un buen suboficial de aviación" (Wegmann 50).

La educación militar es de tendencia humanística y técnica, pero al mismo tiempo debe cumplir ciertas obligaciones militares. La labor se hace intensa y las jornadas duras, pero los frutos serán espléndidos, porque egresará como todo un "profesional": 
...allí terminaría los estudios, y egresaría como cabo y ganando un sueldo (...) No sería piloto, lo sabía ${ }^{17}$, pero aprendería la técnica de sus poderosos motores y la razón por la cual esas enormes y pesadas máquinas se elevaban en el aire, emulando a los pájaros. (...) Cumpliendo la reglamentación, le correspondía elegir especialidad, de acuerdo con su promedio de notas, y prefirió mecánica de aviones, porque le apasionaba, más que nada, el misterio de los poderosos motores (Wegmann 34-36).

Pero analicemos la profesión de Lientur: técnico, no piloto. El indígena no vislumbra que su instrucción solo le abre camino en la sociedad como mano de obra barata, que sin ir más lejos es lo que las misiones reduccionales buscaron desde sus inicios (Giménez). El perfeccionamiento al que es sometido Lientur no lo posiciona de igual a igual con los chilenos, es un ciudadano a medias. Solo pertenece en la medida en que sus potencialidades pueden ser aprovechadas por los otros, teniendo en este caso más deberes que derechos dentro de la comunidad. Su educación sigue ostentando el carácter instructivo de sus primeros años en el colegio-internado: leer, escribir, catequesis; a los que ahora se suman las ciencias básicas para un mejor desempeño de su labor técnica.

Muy pocas veces su "cara de nativo" atenta contra su aparente calma interior y cuando sucede sabe como responder: "Un compañero le preguntó, por el origen de su apellido, sin duda extranjero, en circunstancias de que él era moreno (...) Petáyem buscó una salida, diciendo que su padre era chileno, sus antepasados quizás extranjeros y que él se parecía a su madre, que era chilenísima" (Wegmann 35).

Ante este panorama, la inclusión no se extiende más allá del dominio de las normas socio-culturales, sin embargo, son estas mismas las que lo introducen en la mecánica de las formas de pensamiento cristiano-occidental bajo las cuales ha sido estrictamente adoctrinado, dificultando la segunda parte del plan misional del padre Torres: un posible retorno a la bahía para educar a otros kaweskar. Este objetivo parece ya no tener sentido considerando que la anulación de sus saberes y lengua nativa ha provocado su desarraigo con sus orígenes. Pese a lo fallido del plan "divino" los reclamos de las autoridades militares instando su regreso son constantes:

${ }^{17}$ Las cursivas son mías. 
No olvides que cuando don Pedro se interesó por ti, fue para que te educaras y volvieras a servir a tus hermanos de raza. No olvides, además, que tus padres envejecen y que ya no pueden cazar ni pescar. A tu padrino Aguilar y a mí nos ha extrañado tu silencio. Yo decidí escribirte, para que el día de mañana no tengas el pretexto de que nadie te informó de lo que ocurre en Puerto Edén, de que tus padres no están bien y requieren de tu ayuda (Wegmann 52).

Se ha casado con una chilena que ignora su pasado, pero debemos decir que es una unión bendecida y reglamentada, obedeciendo así al segundo paso natural de la conversión después del bautismo: el matrimonio monogámico (Nicoletti). De esta manera, Lientur ha obedecido todos los preceptos que conllevan la conversión y el bautismo cerrando el círculo, ya no practica los ritos alacalufes y se ha olvidado de su lengua -herramienta atávica y de comprensión del medio para los kaweskar.

\section{IV.- CALAFATEANDO LA ÚLTIMA CANOA O UNA POSIBLE CONCLUSIÓN}

La imagen del fueguino que Wegmann construye en la novela es similar a la que la sociedad chilena y magallánica tenía a comienzos del siglo XX: un ser inferior, domesticable, ridiculizado y discriminado. Podríamos afirmar que el camino de Lientur no contempla el regreso a Puerto Edén, concluyendo así una exitosa incorporación. El indígena se sustenta a sí mismo conviviendo con otros miembros de su clase trabajadora. Hasta podríamos aventurar que la intención de Wegmann es concluir el relato en este punto si no fuera por dos acontecimientos que alteran el orden del plan y que darían materia sustancial para tratar en otro artículo. El benefactor del joven técnico -el Presidenteha muerto y el padre Torres ya envejecido se ha retirado a Europa; Lientur experimenta gravemente el estado de abandono que la supuesta exitosa incorporación le ha otorgado. Creo que este dramático momento no estaba contemplado en el plan misional, cambiando las reglas del juego y dejando al indígena a merced de sus pensamientos, cuestionando su pertenencia a la sociedad chilena y la valoración de su persona como miembro de la sociedad. Cuando el refuerzo se silencia no opera en el sujeto mismo la certeza de la inclusión. Toda su educación ha sido un experimento, un pretexto para sustentar el éxito de la conversión. El aprecio por su inteligencia y eficiencia laboral son producto de la falacia que pretende afianzar las aspiraciones de los 
estamentos del poder sobre las etnias. Cuando éste falla el indígena vuelve a ser el "otro" que regresa a refugiarse en el seno meridional donde nació, concluyendo sus penurias en las aguas de sus antiguos canales.

La narración constituye un recorrido antropológico donde el lector cómplice puede ingresar al túnel acuoso de los canales magallánicos y navegar sobre la última canoa calafateada por las experiencias de esos individuos cuyas existencias resisten en la intemperie de las costas australes.

La última canoa que Petáyem construye a su regreso intensifica el esperado reencuentro entre la Tierra del Fuego y el kaweskar pródigo. La riqueza de significados que ésta alberga es inmenso, atravesando la propia existencia del indígena: en las aguas del Estrecho y montado en su canoa, su muerte sellará para siempre el agónico deceso de su etnia. Al mismo tiempo, la canoa es el símbolo de la revalorización de la identidad kaweskar por medio del rescate de un elemento trascendental para la cultura kaweskar, que como otros bordea los límites del olvido y el abandono. Este y otros conocimientos se han perdido; hoy la última canoa fueguina se exhibe en un museo de Punta Arenas.

\section{BIBLIOGRAFÍA}

Aguilera, Óscar. “Kawésqar”. Lenguas y culturas de Chile. Noviembre 2008 http://www. kawesqar.uchile.cl.

Anderson, Benedict. Comunidades imaginadas. Reflexiones sobre el origen y la difusión del nacionalismo. México: Fondo de Cultura Económica, 1993.

Blengino, Vanni. La zanja de la Patagonia. Los nuevos conquistadores: militares, científicos, sacerdotes, escritores. Buenos Aires: Fondo de Cultura Económica, 2005.

Canclini, Arnoldo. Hasta lo último de la tierra. Allen Gardiner y las misiones en Patagonia. Buenos Aires: Editorial "La Aurora”, 1951.

Clairis, Christos. El Qawasqar. Lingüistica Fueguina Teoría y Descripción. Estudios Filológicos. Anejo 12. Valdivia: Facultad de Filosofía y Humanidades, Universidad Austral de Chile, 1985.

Emperaire, Joseph. Los nómades del mar. Santiago: LOM Ediciones, 2002.

Giménez, Ángel. Las misiones de la Patagonia y la civilización del indio. Buenos Aires: Imp. Escoffier, Caracciolo y Cía., 1917.

Guillaume, Marc. “El otro y el extraño”. Revista de Occidente 140 (1993): 43-58.

Kulawik, Krystof. "El discurso de la liminalidad y de la simultaneidad: las múltiples identidades latinoamericanas". Latinoamérica en la globalización y el tercer milenio. Frontera y Globalización. Tomo I. Ed. Lepoldo Zea y Hernán Taboada. México: Fondo de Cultura Económica, 2002. 23-32. 
Kuzmanich, Simón. "Visión de futuro de Monseñor José Fagnano". Boletín Salesiano 61 (1990): 8-10.

Larraín, Jorge. Identidad Chilena. Santiago: LOM Ediciones, 2001.

Martinic, Mateo. Breve Historia de Magallanes. Punta Arenas: Ediciones de la Universidad de Magallanes, 2002.

Mignolo, Walter. Historias locales/Diseños globales. Colonialidad, conocimientos subalternos y pensamiento fronterizo. Madrid: Ediciones Akal, 2002.

Nicoletti, Andrea. "El imaginario de la conversión en las misiones salesianas de la Patagonia". ARCHIVUM 19 (2000): 247-264.

Odone, Carolina y Pedro Mege. "Imágenes misionales. Sueños y fotografías del extremo sur. Isla Dawson, Tierra del Fuego, 1889-1911”. FUEGUINOS. Fotografias siglo XIX y XX. Imágenes e imaginarios del fin del mundo. Ed. Margarita Alvarado, Carolina Odone, Felipe Maturana y Dánae Fiore. Santiago: Pehuén, 2007. 37-48.

Vega Delgado, Carlos. Sombras de Fuego-Patagonia. Patagonia Fire Shadows. Punta Arenas: Editorial Atelí y Cía. Ltda., 1995.

Wegmann, Osvaldo. La última canoa. Punta Arenas: Hersaprint Ltda., 1976.

Ygobone, Aquiles. Misiones Patagónicas. Buenos Aires: Editorial El Ateneo, 1946.

Zúñiga, Raúl. "Centenario de la presencia salesiana en Porvenir". Boletín Salesiano. 100 (1998): 6-12. 